\title{
Physical properties of sunflower seeds during drying
}

\section{Propriedades físicas dos grãos de girassol durante a secagem}

\author{
Thaís Adriana de Souza Smaniotto ${ }^{*}$; Osvaldo Resende ${ }^{1}$; \\ Kelly Aparecida de Sousa ${ }^{1}$; Rafael Cândido Campos ${ }^{1}$; \\ Denner Nogueira Guimarães ${ }^{1}$; Gabrielly Bernardes Rodrigues ${ }^{1}$
}

\begin{abstract}
The aim of this work was to determine the effect that the moisture content has on the physical properties of sunflower seeds. The cultivar Olisun 3, with an initial moisture content of 34.1 ( $\% \mathrm{wb}$ ), was used and then subjected to drying in an oven with forced air ventilation under three temperature conditions: 40 , 60 and $80{ }^{\circ} \mathrm{C}$. The reduction in the moisture content during drying was monitored by the gravimetric method until it reached a final moisture content of $8.0 \pm 1.0(\% \mathrm{wb})$. The physical properties were analysed: the bulk density, true density, intergranular porosity and volumetric shrinkage of the mass and unit and terminal velocity. The reduction in the moisture content influenced the physical properties of sunflower seeds and caused a decrease in the intergranular porosity, bulk density and true density at all examined temperatures. The mass and volumetric contractions of the unit and reduction in shrinkage rates all increased with the drying of sunflower seeds at all studied temperatures. The terminal velocity increased as the moisture content of the grains increased, which was more evident at the drying temperature of $80^{\circ} \mathrm{C}$.
\end{abstract}

Key words: Moisture content. Helianthus annuи. Intergranular porosity. Volumetric shrinkage.

\section{Resumo}

Objetivou-se neste trabalho, determinar o efeito do teor de água sobre as propriedades físicas dos grãos de girassol. Foram utilizados grãos da cultivar Olisun 3 com teor de água inicial de 34,1 (\% b.u.) e posteriormente submetidos à secagem em estufa com ventilação de ar forçada em três condições de temperatura: 40,60 e $80^{\circ} \mathrm{C}$. A redução do teor de água ao longo da secagem foi acompanhada pelo método gravimétrico, conhecendo-se o teor de água inicial do produto, até atingir o teor de água final de $8,0 \pm 1,0$ (\% b.u.). As propriedades físicas analisadas foram: massas específicas aparente e unitária, porosidade intergranular, bem como contração volumétrica da massa e unitária e velocidade terminal. A redução do teor de água influencia as propriedades físicas dos grãos de girassol, proporcionando a diminuição da porosidade intergranular e das massas específicas aparente e unitária em todas as temperaturas de secagem analisadas. As contrações volumétricas da massa e unitária diminuem e os índices de contração aumentam com a secagem dos grãos de girassol em todas as temperaturas avaliadas. A velocidade terminal aumenta à medida que eleva o teor de água dos grãos, sendo mais evidente na temperatura de secagem de $80^{\circ} \mathrm{C}$.

Palavras-chave: Teor de água. Contração volumétrica. Helianthus annuus. Porosidade intergranular. Contração volumétrica.

\footnotetext{
${ }^{1}$ Pesquisadores, Instituto Federal de Ciência Educação e Tecnologia, Rio Verde, GO, Brasil. E-mail: thais.souza.smaniotto@ gmail.com; osvresende@yahoo.com.br; kellyapsousa@yahoo.com.br; rcandido30@gmail.com; denner-rv@hotmail.com; gabybrodrigues@hotmail.com

* Author for correspondence
} 
Among the post-harvest processes that are used to maintain the quality of agricultural products, drying is the most widely used as a means to reduce both the biological activity and the chemical and physical changes that occur during storage. According to Goneli et al. (2011), information on the size, volume, porosity and density of agricultural products is considered relevant for studies on energy and mass transfer as well as air movement in granular masses.

Each medium has unique physical and chemical characteristics, and such media thus behave differently during the drying process. Therefore, information regarding this uniqueness is significant for post-harvest processing and can provide a set of data to engineers and designers that will support the development of machines, structures, and process controls to improve the efficiency of equipment or operations (ARAÚJO et al., 2014).

The volumetric changes of the products are reported to be the main causes of changes in the physical properties of agricultural grains. The shrinkage ratio determines the ratio between the volume of the grains at each moisture content and initial volume. This index has an outstanding influence during the drying process and can predict the reduction in the volume occupied by the grain mass because this volume is caused by the reduction in the moisture content (SIQUEIRA et al., 2012).

The bulk density and existing intergranular porosity in the grain mass are parameters that are required for the efficient design of reception structures, handling, processing and storage of grain. The intergranular porosity is linked to the resistance that the grain layer provides the movement of air and depends directly on the shape, size, and other characteristics of the material. The bulk density is the ratio of the mass of a certain volume of grains, including voids. According to Corrêa and Silva (2008), the bulk density can also be used to determine the moisture content, insect damage, and fungal spoilage in products.
Because of the importance of the knowledge of the physical properties of the grains, the objective of this study was to determine the effect that the moisture content and drying air temperature have on the physical properties of sunflower seeds.

The study was conducted at the Laboratory of Postharvest Vegetable Products of the Federal Institute of Education, Science and Technology (IF Goiano - Campus Rio Verde), located in the city of Rio Verde, GO.

The sunflower seeds used were Olisun 3, with an initial moisture content of 34.1 ( $\%$ wb), and were subjected to drying in an oven with forced air ventilation under three temperature conditions: 40 , 60 and $80^{\circ} \mathrm{C}$. The relative humidity of the drying air was controlled by means of a psychrometer installed inside the oven. The reduction in the moisture content during drying was monitored by gravimetric conditions (weight loss), using the initial moisture content of the product until it reached a moisture content of $8.0 \pm 1.0(\% \mathrm{wb})$.

The monitoring of the mass reduction during drying was carried out using an analytical balance with a resolution of $0.01 \mathrm{~g}$. The moisture content was determined using the oven method (BRASIL, 2009). During drying, the moisture content for each sample was 34.0, 28.0, 21.0, 16.0, 11.0 and $8.0(\%$ wb); then, the samples were homogenized, and their physical properties were determined in three replications.

The physical properties analysed were the bulk density, true density, volumetric shrinkage of the mass and unit, intergranular porosity and terminal velocity.

The intergranular porosity (e) was determined using a beaker containing $100 \mathrm{~mL}$ of sunflower seeds, to which a known amount of hexane was added, with the aid of a $50 \mathrm{~mL}$ burette to fill the empty spaces of the mass. Hexane was used, as recommended by Donadon et al. (2012). The intergranular porosity was obtained by measuring the amount of hexane added to the dough product, and the results were expressed as a percentage. 
The bulk density ( $\mathrm{r}$ ), in $\mathrm{kg} \mathrm{m}^{-3}$, was determined using an electronic scale with a hectolitre weight resolution of 0,1 g (GEHAKA - BK 4001), using a container capable of holding $1000 \mathrm{~mL}$. The true density $\left(\mathrm{r}_{\mathrm{t}}\right)$, in $\mathrm{kg} \mathrm{m}^{-3}$, was obtained indirectly on the basis of intergranular porosity and bulk density according to the equation described by Mohsenin (1986):

$$
\rho_{\mathrm{t}}=\frac{\rho}{(1-\varepsilon)}
$$

where

$\rho:$ bulk density, $\mathrm{kg} \mathrm{m}^{-3}$;

$\rho_{\mathrm{t}}$ : true density, $\mathrm{kg} \mathrm{m}^{-3}$;

$\varepsilon$ : porosity, decimal.

The shrinkage of mass $\left(\psi_{\mathrm{m}}\right)$ was determined using a $250 \mathrm{~mL}$ test tube. For each moisture content, the sunflower grains were placed in the beaker with the aid of a funnel with a pre-established height of $0.36 \mathrm{~m}$, and the unit shrinkage $\left(\psi_{\mathrm{u}}\right)$ during drying was determined by the relationship between the volume for each moisture content and the initial volume.

The shrinkage of the mass index $\left(\ddot{\mathrm{I}} \psi_{\mathrm{m}}\right)$ and the unit shrinkage índex $\left(\ddot{\mathrm{I}} \psi_{\mathrm{g}}\right)$ were obtained using the following expression, and the results were expressed as a percentage:

$$
\mathrm{I} \psi=\left(\psi_{0}-\psi_{\mathrm{t}}\right) \cdot 100
$$

where

$\ddot{I} \psi=$ shrinkage unit and mass index, $\%$;

$\psi_{0}=$ initial shrinkage unit and mass index, decimal;

$\psi_{\mathrm{t}}=$ shrinkage in time $\mathrm{t}$, decimal.
The experimental terminal velocity (Vt) was assessed using the equipment air column (Figure 1), which was composed of a centrifugal fan connected to a transparent acrylic tube with a diameter of $0.150 \mathrm{~m}$ and a length of $2.30 \mathrm{~m}$. A perforated screen was installed $2.15 \mathrm{~m}$ from the top to ensure the placement of the product. A crosslinker was coupled to equalize the distribution of air velocity in the tube cross section. The fan was powered by a threephase motor of $1.5 \mathrm{hp}(1.10 \mathrm{~kW})$, and the diaphragm controlled the flow of air.

The terminal velocity was determined in four replicates for each of the six moisture content levels for sunflower seeds that had previously been dried at temperatures ranging from 60 to $80^{\circ} \mathrm{C}$. The seeds were weighed and spread in the central part of the perforated screen in 15.0-g samples (SILVA et al., 2003). The air flow was set to the beginning of the product flotation process and then to an anemometer positioned in three distinct parts of the air outlet tube to obtain air velocity readings.

The experiment was conducted in a factorial scheme $3 \times 6$, with three drying temperatures (40, 60 and $80{ }^{\circ} \mathrm{C}$ ) and six moisture content levels (34.0, $28.0,21.0,16.0,11.0$ and $8.0 \% \mathrm{wb}$ ) in a randomized design. For the terminal velocity, the experiment was conducted according in a factorial $2 \times 6$ scheme, with two drying temperatures $\left(60\right.$ and $80{ }^{\circ} \mathrm{C}$ ) and six moisture content levels $(24.0,20.0,16.0,12.0$, 8,0 and $4.0 \% \mathrm{wb}$ ) in a randomized design. The data were analysed by a regression performed in the Sisvar program.

Concerning the results obtained, Figure 2 shows the experimental and estimated values of the apparent density (A) and unit shrinkage (B) in sunflower seeds as a function of the moisture content $(\% \mathrm{wb})$. 
Figure 1. Experimental and estimated values of bulk density (A), true density (B), intergranular porosity (C) and terminal velocity (D) of sunflower seeds as a function of the moisture content (\% wb).

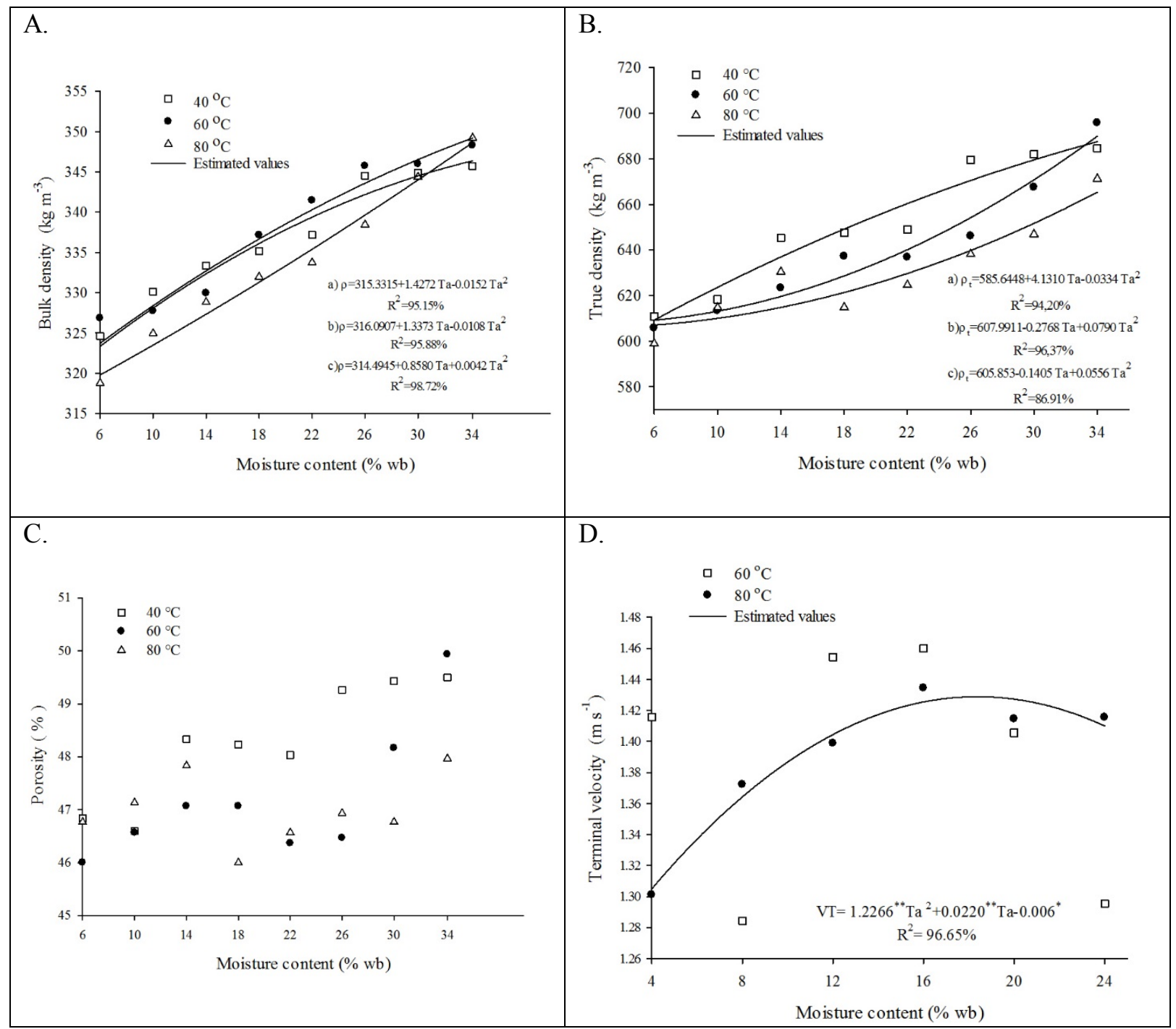

** Significant at $1 \%$ by $\mathrm{t}$ test; * Significant at $5 \%$ by t test; ${ }^{\mathrm{ns}}$ no significant, $\mathrm{MC}$ : moisture content.

This study verified that there was a reduction in the bulk density of sunflower seeds with reduced moisture content at all temperatures studied. Araújo et al. (2014) also observed a reduction in the bulk density in the process of drying peanut seeds and reported that this may be associated with greater contraction inside the cotyledons in relation to its external dimensions shrink to a lesser extent, thus forming empty spaces inside the grain. When there is less reduction in the volume of the product relative to the higher weight loss (water) during drying, the bulk density of the grains decreases. The values of the bulk density ranged from 345.70 at 324.60 , 348.29 at 326.83 to 349.23 at $318.77 \mathrm{~kg} \mathrm{~m}^{-3}$ at 40 , 60 and $80{ }^{\circ} \mathrm{C}$, respectively, and were satisfactorily represented by the quadratic regression.

Figure 1B shows a similar result to those observed for the apparent density or a reduction in the drying process, probably due to the combined effect of the grain deformation and the presence of voids therein, whereas the mass reduction occurs therein. These empty spaces from the morphology of the fruit are 
called achenes, whereas the seed joins the wall of the fruit by only one point. Goneli et al. (2008) observed the same behaviour when working with castor bean seeds, which have voids within, and noted that little shrinkage occurred during drying, which caused the volume of the seeds to remain constant; however, there was a reduction in its mass upon drying.

Figure 2. Experimental and estimated values of the shrinkage mass (A), shrinkage mass ratio (B) unit shrinkage (C) and unit shrinkage rate (D) of sunflower seeds as a function of the moisture content ( $\% \mathrm{wb}$ )

A.

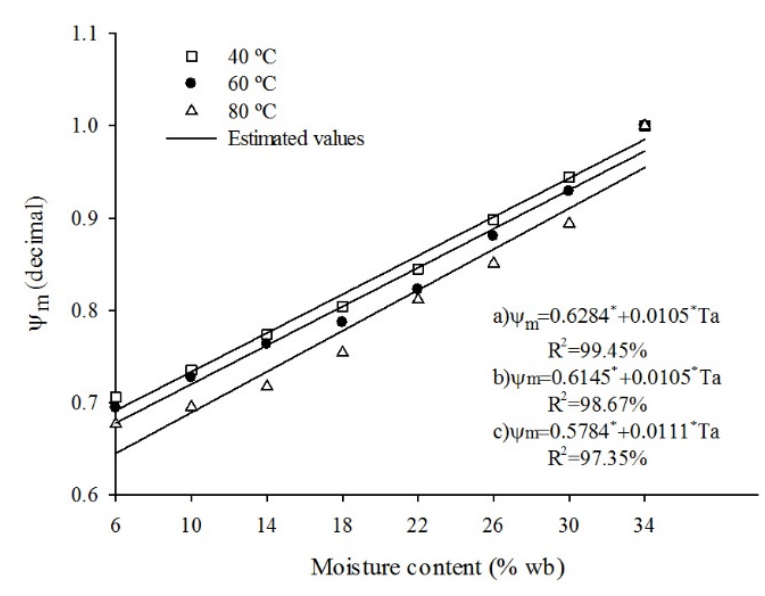

C.

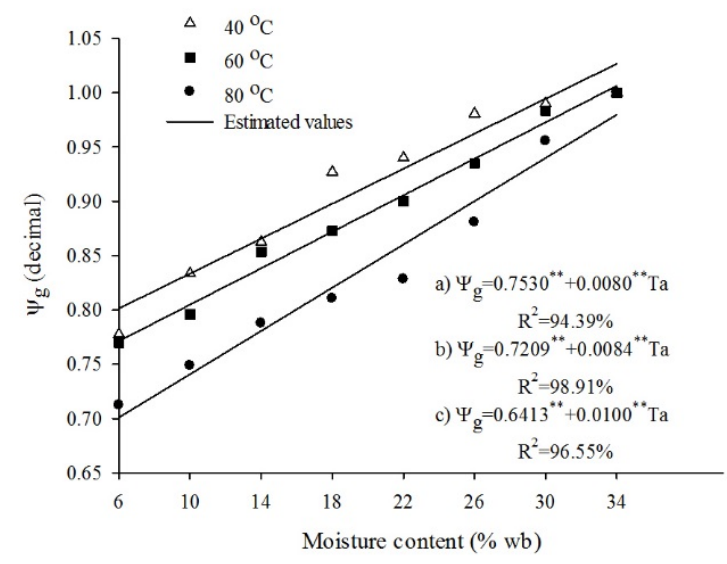

B.

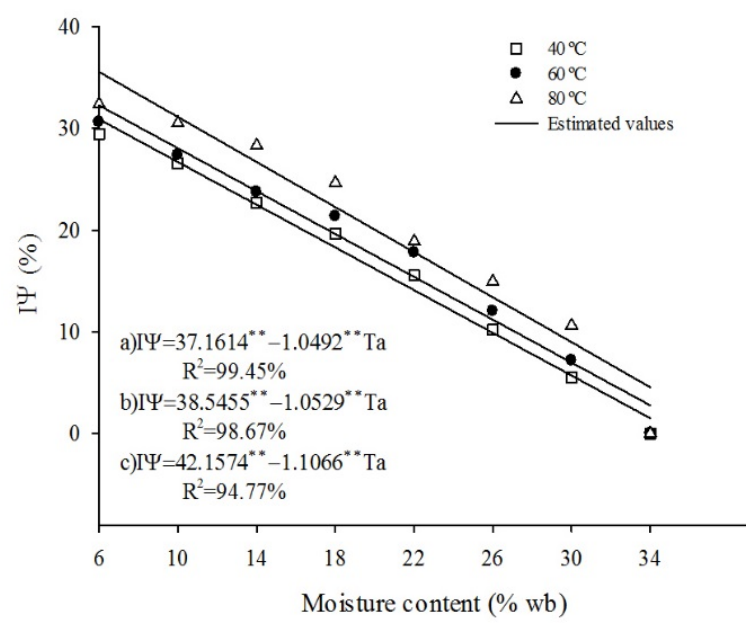

D.

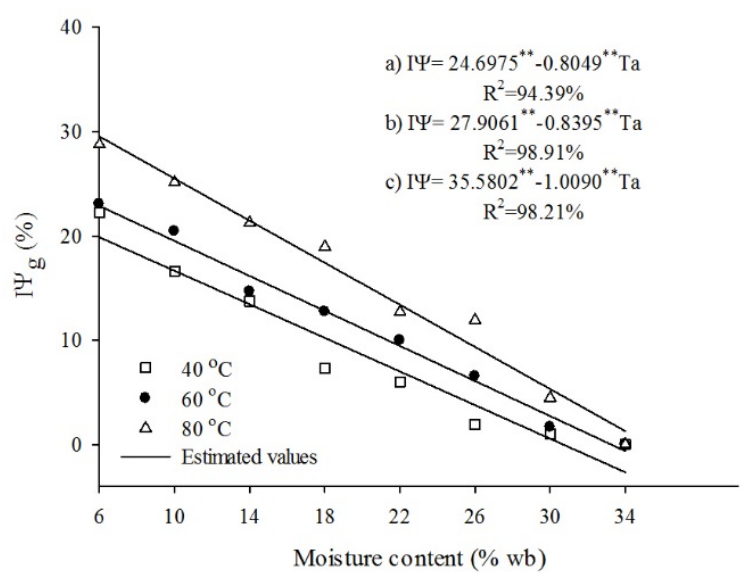

** Significant at $1 \%$ by $\mathrm{t}$ test; * Significant at $5 \%$ by $\mathrm{t}$ test; ${ }^{\mathrm{ns}}$ no significant; MC: moisture content.

The true density values of sunflower seeds ranged from 684.6 to $610.7,695.7$ to 605.7 and 671.2 to $598.9 \mathrm{~kg} \mathrm{~m}^{-3}$ at 40,60 and $80^{\circ} \mathrm{C}$, respectively. It was also observed in Figure $1 \mathrm{~B}$ that the reduction in the values of the true density of sunflower seeds can be satisfactorily represented by the quadratic regression.

Figure $1 \mathrm{C}$ shows the experimental values and estimated porosity of the mass of sunflower seeds as a function of the moisture content. It is observed that the intergranular porosity values decrease with the reduction in the moisture content of sunflower seeds at all temperatures studied. We could not see a clear trend in terms of the moisture content, so there is no equation to represent this feature. According to Mcminn and Magee (1997), the reductions in intergranular porosity are due to the structural 
changes associated with the cellular product changes that occur following the removal of water during the drying process. The values were 49.5 to 46.8 , 46 to 49.93 and 47.9 to $46.7 \%$ at 40,60 and $80{ }^{\circ} \mathrm{C}$, respectively. Lanaro et al. (2011) and Goneli et al. (2008) also observed reductions in the intergranular porosity during the drying process for black-eyed beans and castor oil, respectively.

Figure 2A shows the experimental and estimated values of shrinkage of the mass of sunflower seeds as a function of the moisture content. There is a decrease in the volume of the mass shrinkage when the moisture content is reduced at all temperatures studied. This decrease is due to a reduction in tissue size that occurs as a result of a decrease in the moisture content during the drying process. The volume of the sunflower seeds was reduced by 29 , 31 and $32 \%$ with a reduction in moisture content at 40,60 and $80{ }^{\circ} \mathrm{C}$, respectively.

The mass reduction in the contraction values for sunflower seeds can be satisfactorily represented by the linear regression model. Goneli et al. (2011) observed a $63 \%$ reduction in the mass of the fruit in relation to the initial volume by working with castor beans for the moisture content from 2.50 to $0.13(\mathrm{db})$. Afonso Júnior et al. (2003) observed a decrease of $35 \%$ in the volume of the coffee cherry fruit by reducing the moisture content from 2.27 to 0.11 (db), and Resende et al. (2005), working with beans, found a reduction in the initial volume of grains of $46.1 \%$, with a moisture content ranging from 0.92 to $0.13(\mathrm{db})$. The shrinkage of the grain mass provides voids within which the dryer increases the passage of hot air and can increase the risk of dryer fire.

Figure $2 \mathrm{~B}$ shows that there was an increase in the volumetric shrinkage rate in the drying process; i.e., there was a decrease in the initial volume of sunflower seeds, with values of 29.4, 30.6 and $32.4 \%$ at 40,60 and $80{ }^{\circ} \mathrm{C}$, respectively, and this is satisfactorily represented by a linear regression model. Figure $2 \mathrm{~B}$ also shows that the increase in temperature produced greater shrinkage values in sunflower seeds. For each increase of $1 \%(w b)$ in moisture content, the mass shrinkage decreased by, on average, $3.68,3.82$ and 4.05 at 40,60 and $80{ }^{\circ} \mathrm{C}$, respectively.

It is noted that the unit shrinkage during drying decreased at all temperatures studied, with values of $0.78,0.77$ and 0.71 at 40,60 and $80{ }^{\circ} \mathrm{C}$, respectively (Figure 2C). These data corroborate those obtained by Oliveira et al. (2013), who worked with soybeans and found that the linear model adequately represents the shrinkage rate relative to the moisture content. Goneli et al. (2011) reported a reduction in the fruit size of castor dried at $40{ }^{\circ} \mathrm{C}$, which reached approximately 0.55 for the final moisture content of $0.13(\mathrm{db})$, for a reduction of $46 \%$ compared to its initial volume.

For the unit shrinkage rate of sunflower seeds (Figure 2D), there was an increase in the shrinkage index of sunflower seeds as drying occurred at all measured temperatures. The temperature of $80{ }^{\circ} \mathrm{C}$ showed a higher index compared to the others, with $29 \%$ grain contraction compared to the initial volume against 22.2 and $23 \%$ for the temperatures of 40 and $60{ }^{\circ} \mathrm{C}$, respectively. Oliveira et al. (2013) found that the shrinkage ratio of soybeans decreased when dried at two temperatures $\left(50\right.$ and $\left.90{ }^{\circ} \mathrm{C}\right)$. Resende et al. (2005) also found a reduction from 35.8 to 46.1 in the moisture content range from 0.92 to 0.13 (db. decimal), respectively, for beans.

Figure 2D also shows that the increasing unitary contraction values for sunflower seeds can be satisfactorily represented by a linear regression model. For each increase of $1 \%(\mathrm{wb})$ in the moisture content, the unit shrinkage rate increases to 3.18 ; 3.29 and 4.11 at 40,60 and $80{ }^{\circ} \mathrm{C}$, respectively.

Figure 1D shows the experimental values and estimated terminal velocities of sunflower seeds as a function of moisture content $(\% \mathrm{wb})$. There is an increase as the moisture content of the grains increases, which is more evident in the beans dried at $80^{\circ} \mathrm{C}$. Silva et al. (2003) found a linear increase in 
the terminal velocity in grain sorghum and millet as the moisture content increased in grains and reported that this increase was due to changes in the physical characteristics of the product, thus confirming the expectation that the increased presence of water in the formula contributes decisively to the direct change in the relationship between the mass and volume of the grain and increases the terminal velocity values.

It appears that even the quadratic equation can be used to express the behaviour of the terminal velocity of sunflower seeds at $80{ }^{\circ} \mathrm{C}$. This finding also shows that the maximum terminal velocity reached is $1.429 \mathrm{~m} \mathrm{~s}^{-1}$, and the maximum moisture content is $18.4(\% \mathrm{wb})$. Gürsoy and Güzel (2010) worked with barley and wheat grains and found values ranging from 7.52 to 8.4 and 7.04 to $7.07 \mathrm{~m}$ $\mathrm{s}^{-1}$ for wheat and barley, respectively. Razavi et al. (2007) found the moisture content ranging from 8.30 to $4.0(\% \mathrm{wb})$ in pistachio seeds. Therefore, it can be inferred that the sunflower has a relatively low terminal velocity, which hinders the separation of impurities in the separation and cleaning processes.

At the drying temperature of $60{ }^{\circ} \mathrm{C}$, there was a change in the terminal velocity values, starting with a decrease in the moisture content of 8.0 (\% wb), followed by an increase until the moisture content of $16.0(\% \mathrm{wb})$ and a subsequent reduction. Benedetti and George (1992) found that the terminal velocity of paddy rice, beans, corn, soy and wheat increases with increasing moisture content to approximately $18-22(\% \mathrm{wb})$ and decreases at increasing moisture levels above that.

\section{Conclusions}

Reducing the moisture content influenced the physical properties of sunflower seeds and resulted in a decrease in the intergranular porosity, bulk density and true density at the three drying temperatures analysed.
The shrinkage mass and unit reductions and the shrinkage rates increased with the drying of sunflower seeds at all of the drying temperatures evaluated.

The terminal velocity increased as the moisture content of the grains increased, which was more evident at the drying temperature of $80{ }^{\circ} \mathrm{C}$.

\section{References}

AFONSO JÚNIOR, P. C.; CORRÊA, P. C.; PINTO, F. A. C.; SAMPAIO, C. P. Shrinkage evaluation of five different varieties of coffee berries during the drying process. Biosystems Engineering, Cambridge, v. 86, n. 4, p. 481-485, 2003.

ARAÚJO, W. D.; GONELI, A. L. D.; SOUZA, C. M. A.; GONÇAlVES, A. A.; VILHASANTIS, H. C. B. Propriedades físicas dos grãos de amendoim durante a secagem. Revista Brasileira de Engenharia Agrícola e Ambiental, Campina Grande, v. 18, n. 3, p. 279-286, 2014.

BENEDETTI, B. C.; JORGE, J. T. Influência do Teor de umidade sobre a velocidade terminal de vários grãos. Engenharia Agrícola, Botucatu, v. 12, p. 102-118, 1992.

BRASIL. Ministério da Agricultura e Reforma Agrária. Secretaria Nacional de defesa Agropecuária. Regras para análise de sementes. Brasília: Mapa/ACS, 2009. 395 p.

CORRÊA, P. C.; SILVA, J. S. Estrutura, composição e propriedades dos grãos. In: SILVA, J. S. Secagem e armazenagem de produtos agrícolas. 2. ed. Viçosa, MG: Ed. Aprenda Fácil, 2008. p. 19-36.

DONADON, J. R.; RESENDE, O.; CASTRO, C. F. S.; MENDES, U. C.; GONÇASVES, D. N. Comparação entre o tolueno e o hexano na determinação da porosidade intergranular de diferentes produtos agrícolas. Revista Brasileira de Armazenamento, Viçosa, MG, v. 37, n. 2, p. 37-40, 2012.

GONELI, A. L. D.; CORRÊA, P. C.; BOTELHO, F. M.; OLIVEIRA, G. H. H.; SANTOS, E. S. Propriedades físicas dos frutos de mamona durante a secagem. Revista Brasileira de Armazenamento, Viçosa, MG, v. 33, n. 2, p. 148-155, 2008.

GONELI, A. L. D.; CORRÊA, P. C.; MAGALHÃES, F. E. A.; BAPTESTIN, F. M. Contração volumétrica e forma dos frutos de mamona durante a secagem. Acta Scientiarum. Agronomy, Maringá, v. 33, n. 1, p. 1-8, 2011. 
GÜRSOY, S.; GÜZEL, E. Determination of physical properties of some agricultural grains. Research Journal of Applied Sciences, Engineering and Technology, v. 2, n. 5, p. 492-498, 2010.

LANARO, N. D.; BAJAY, G.; QUEIROZ, V. M. P.; PINTO, R. C. S.; LEITÃO, I. G. A.; LESSIO, B. C.; AUGUSTO, P. E. D. Determinação de propriedades físicas do feijão fradinho. Revista Brasileira de Produtos Agroindustriais, Campina Grande, v. 13, n. 1, p. 27-35, 2011.

MCMinN, W. A. M.; MAGEE, T. R. A. Physical characteristics of dehydrated potatoes part I. Journal of Food Engineering, Essex, v. 33, n. 1-2, p. 37-48, 1997.

MOHSENIN, N. N. Physical properties of plant and animal materials. New York: Gordon and Breach Publishers, 1986.

OLIVEIRA, D. E. C.; RESENDE, O.; SMANIOTTO, T. A. S.; SIQUEIRA, V. C.; JOSÉ NETO, C. A. Alterações morfométricas em grãos de soja durante o processo de secagem. Semina: Ciências Agrárias, Londrina, v. 34, n. 3, p. 975-984. 2013.
RAZAVI, S. M. A.; RAFE, A.; AKBAR, R. Terminal velocity of pistachio nut and its kernel as affected by moisture content and variety. African Journal of Agricultural Research, Lagos, v. 2, n. 12, p. 663-666, 2007.

RESENDE, O.; CORRÊA, P. C.; GONELI, A. L. D.; CECON, P. R. Forma, tamanho e contração volumétrica do feijão (Phaseolus vulgaris L.) durante a secagem. Revista Brasileira de Produtos Agroindustriais, Campina Grande, v. 7, n. 1, p. 15-24, 2005.

SILVA, F. S.; CORREAA, P. C.; AFONSO JUNIOR, P. C.; GONELI, A. L. D. Influência do teor de umidade na velocidade terminal de grãos de sorgo e milheto. Revista Brasileira de Milho e Sorgo, Sete Lagoas, v. 2, n. 3, p. 143-147, 2003.

SIQUEIRA, V. C.; RESENDE, O.; CHAVES, T. H.; SOARES, F. A. L. Forma e tamanho dos frutos de pinhãomanso durante a secagem em cinco condições de ar. Revista Brasileira de Engenharia Agrícola e Ambiental, Campina Grande, v. 16, n. 8, p. 864-870, 2012. 